\title{
Metamorphic history and tectonic evolution of the Himalayan UHP eclogites in Kaghan valley, Pakistan
}

\author{
Hafiz Ur Rehman ${ }^{*}$, Hiroshi Yamamoto ${ }^{*}$, M. Ayub Khan KhaliL ${ }^{* *}$, Eizo NaKamurA ${ }^{* * *}$, \\ Muhammad ZAFAR ${ }^{* * * *}$ and Tahseenullah $\mathrm{KHAN}^{* * * * *}$ \\ ${ }^{*}$ Department of Earth and Environmental Sciences, Faculty of Science, \\ Kagoshima University, Kagoshima 890-0065, Japan \\ ${ }^{* *}$ Geological Survey of Pakistan, Plot No. 84, Street No. 3, \\ Sector H-8/1, Islamabad, Pakistan \\ ${ }^{* * *}$ The Pheasant Memorial Laboratory, Institute for Study of the Earth's Interior, \\ Okayama University, Misasa 682-0193, Japan \\ ${ }^{* * * *}$ Faculty of Earth and Environmental Sciences, Bahria University, \\ Shangrilla Road, E-8 Islamabad, Pakistan \\ ${ }^{* * * * *}$ Geoscience Laboratory, Geological Survey of Pakistan, \\ Shehzad Town, Islamabad, Pakistan
}

\begin{abstract}
Eclogites of the Kaghan valley, Pakistan Himalaya were investigated petrographically and geochemically. Based on petrography, geochemistry and mineral compositions, metamorphic history and a reasonable tectonic model are proposed. Eclogites exposed in the Kaghan valley are classified into two groups. Group I eclogites appear as massive and Group II are lens-type. Group I eclogites have a mineral assemblage of garnet, omphacitic clinopyroxene, quartz, symplectite with rare epidote and phengite. Accessory minerals include abundant zircon, rutile, ilmenite, and rare apatite. Group II eclogites have a mineral assemblage of garnet, omphacitic clinopyroxene, phengite, quartz/coesite, epidote, and symplectite. In accessory minerals rutile and ilmenite are common while zircon and apatite are rare. Different types of protolith are proposed for these eclogites. Group I eclogites have higher $\mathrm{FeO}$ and $\mathrm{TiO}_{2}$ contents and trace element contents, and seem to be derived from gabbroic protolith. Group II eclogites have lower $\mathrm{FeO}$ and $\mathrm{TiO}_{2}$ and trace element contents and were derived from basalts. Pressure-temperature-time path was constructed for the Kaghan valley eclogites using various mineral assemblages along with textural relationship and inclusions study. At least three distinct metamorphic stages were identified. The first stage is the prograde garnet growth stage deduced from the inclusion paragenesis in garnet core. The second stage records the ultrahigh-pressure metamorphic stage deduced from the presence of coesite inclusions in omphacitic clinopyroxene. The third stage is the decompression stage and is deduced from the quartz-albite-amphibole symplectite portions. These petrological and geochemical results combined with isotopic ages reported elsewhere indicate that basalts and associated gabbroic dikes were emplaced at about $267 \mathrm{Ma}$ when the Indian plate was moving northward and passing above an unknown hot spot. The closure of the Tethys and initiation of collision of the Indian plate with the Kohistan-Ladakh Island Arc is reported from 65-50 Ma. After that the leading-edge of the Indian plate underwent eclogite facies metamorphism at $49 \mathrm{Ma}$ and when it reached to depths of about $100 \mathrm{~km}$, the ultrahigh-pressure metamorphic event took place at $46 \mathrm{Ma}$.
\end{abstract}

Keywords: Kaghan valley, Pakistan Himalaya, Ultrahigh-pressure eclogites, Tectonic model

doi:10.2465/jmps.080222

H.U. Rehman, hafiz@sci.kagoshima-u.ac.jp Corresponding author

H. Yamamoto, hyam@sci.kagoshima-u.ac.jp 


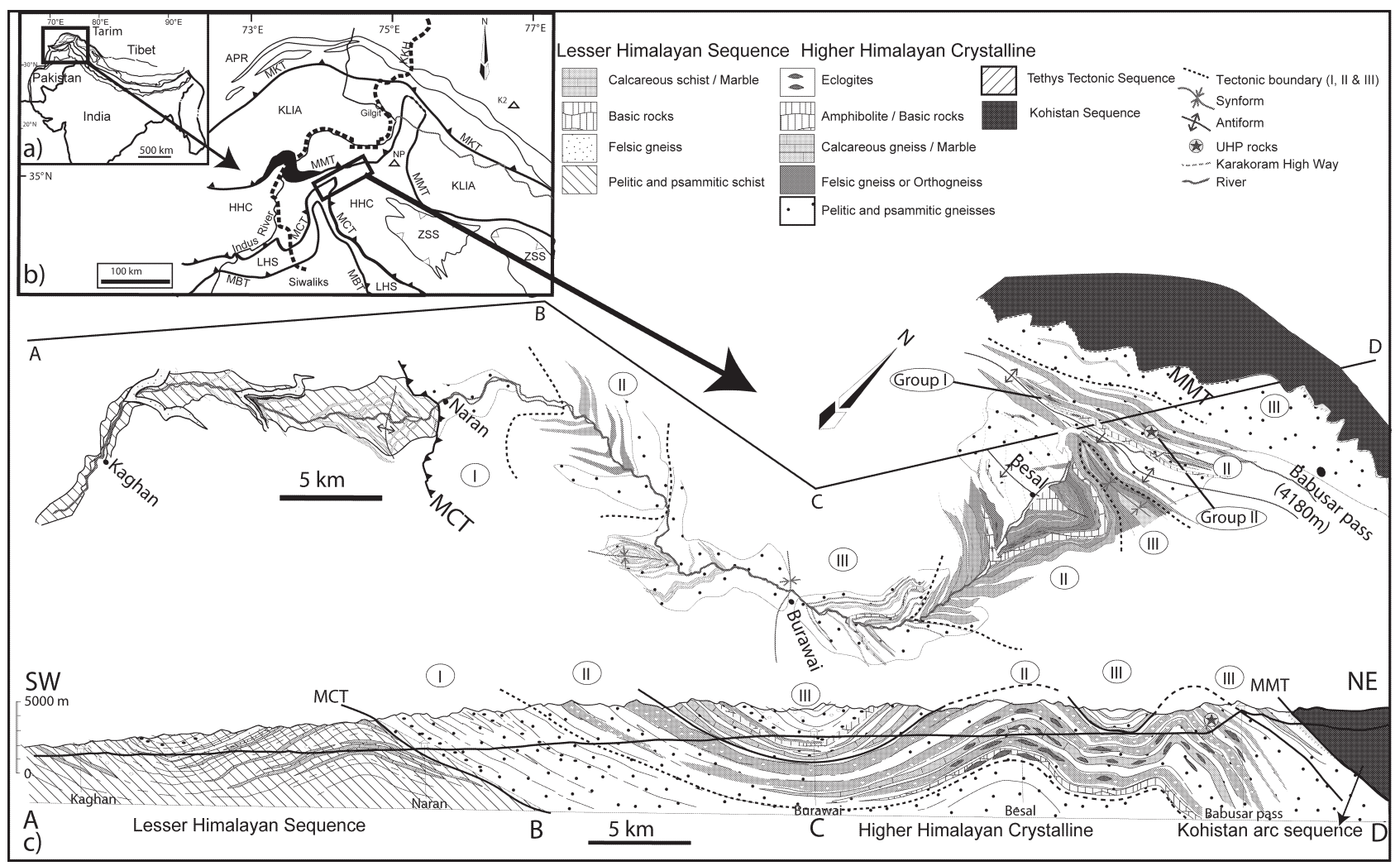

Figure 1. (a) Regional geological map of the Himalayan range. (b) Tectonostratigraphic subdivision of the Indian plate rocks, Kohistan-Ladakh Island Arc and Asian plate rocks. (c) Major lithologic sequences of the Himalayan metamorphic belt with cross-section along the Kaghan valley transect. Abbreviations used in the map and in the text are: LHS, Lesser Himalayan Sequence; HHC, Higher Himalayan Crystalline; KLIA, Kohistan-Ladakh Island Arc; APR, Asian plate rocks; ZSS, Zanskar Shelf Sediments; MBT, Main Boundary Thrust; MCT, Main Central Thrust; MMT, Main Mantle Thrust; MKT, Main Karakoram Thrust; NP, Nanga Parbat. In the HHC three tectonic units are marked as I, II and III, details of which are given in Rehman et al. (2007). UHP eclogites occur in Unit II. The map is modified after Kaneko et al. (2003).

\section{INTRODUCTION}

The occurrence of coesite in metamorphic rocks constrains the minimum pressures and depths of ultrahighpressure (UHP) metamorphism. The presence of coesite inclusions in clinopyroxene from eclogites (O'Brien et al., 2001) and in zircon from felsic gneisses (Kaneko et al., 2003) of the Kaghan valley, north Pakistan, indicates subduction of these rocks to depths exceeding $100 \mathrm{~km}$. Pressure-Temperature $(P-T)$ estimates calculated for the Kaghan valley UHP eclogites are 2.7 to $3.2 \mathrm{GPa}$, and 760 ${ }^{\circ} \mathrm{C}$ to $790{ }^{\circ} \mathrm{C}$ (O'Brien et al., 2001; Kaneko et al., 2003; Rehman et al., 2007). To understand the collision tectonics and to decipher the regional metamorphic processes, geological field and analytical research works were carried out during the last two decades (e.g., Honegger et al., 1982; Greco et al., 1989; Papritz and Rey, 1989; Tonarini et al., 1993; Spencer et al., 1995; Lombardo and Rolfo, 2000; O’Brien et al., 2001; Guillot et al., 2003; Kaneko et al., 2003; Parish et al., 2006 etc.). Rehman et al. (2007) estimated the thermobaric structure along the Kaghan valley transect.
It is believed that amphibolites and eclogites exposed in the Kaghan valley were the products of continental basaltic flows and their preceding feeder dikes of the Permian to Early Triassic Panjal Trap (Honegger et al., 1982; Papritz and Rey; 1989; Spencer et al., 1995). The basaltic extrusions mark start of the volcanic activity at the northern margin of the Indian plate (Honegger et al., 1982, and references therein). Ages of the India-Asia collision and regional metamorphism range from 65 to $43 \mathrm{Ma}$ (e.g., Patriat and Achache, 1984; Klootwijk et al., 1992; Tonarini et al., 1993; Beck et al., 1995; Guillot et al., 2003; Rehman, 2007) with an UHP metamorphic event at $46 \mathrm{Ma}$ (Kaneko et al., 2003). Most of the above workers focused on the India-Asia collision and regional metamorphism, but the origin and source of mafic rocks (amphibolites and eclogites of Kaghan valley) exposed at different localities, was unclear. In the present research we tried (1) to find out the compositional variations in eclogites exposed at different localities, (2) to describe their origin, (3) to construct the pressure-temperature-time path for them, and (4) to present a schematic tectonic model based on all results. 


\section{GEOLOGICAL SETUP}

The Kaghan valley is situated in the western syntaxis area of the Himalayan range (Fig. 1a). The syntaxis area is comprised mainly of the Higher Himalayan Crystalline (HHC) which is delimited by the Main Central Thrust (MCT) in the south and the Main Mantle Thrust (MMT) in the north (Fig. 1b). Structurally, the HHC in the Kaghan valley area can be regarded as to show a largescale synclinorium in the south and an anticlinorium in the north, with repeated synclines and anticlines (Fig. 1c). These strongly folded structures are composed of pelitic and psammitic gneisses, felsic gneisses, calcareous metasediments, mafic dikes and schistose mafic rocks (amphibolite sheets with locally abundant eclogitic bodies). Based on structural setup and metamorphic conditions, rocks of the HHC are classified into three units; I, II and III in tectonically ascending order (for detailed geology of the Units I, II and III see Rehman et al., 2007). Metamorphic grade gradually increases from staurolite grade near MCT in the south (Unit I) to sillimanite grade in the north (Unit III) through kyanite grade (Unit II). It decreases abruptly to chlorite-biotite facies near MMT in the north (Rehman et al., 2007).

Eclogites occur as massive bodies, lenses and thin layers, and are intercalated with felsic/pelitic gneisses and calcareous rocks. Their sizes range from tens of centimeters to a few meters in diameter. The eclogite bodies are elongated along the strike of the foliation of the surrounding pelitic/felsic gneisses and calcareous rocks. Coesitebearing eclogites are found in Unit II (Fig. 1c, represented by star). It appears as an isolated block, less than 2 meters in diameter, in felsic gneisses (Kaneko et al., 2003; Rehman et al., 2007).

\section{METHODS}

Modal abundance (volume\%) of minerals was calculated from thin sections using point counter. Major element compositions of minerals were determined using a JEOL JXA-8600 electron microprobe at the Kagoshima University. Analyses were carried out at $15 \mathrm{kV}$ and $12 \mathrm{nA}$ sample current for all silicate minerals. Counting times of $30 \mathrm{sec}-$ onds were used, and matrix corrections were performed by ZAF oxide methods. The standards used are synthetic oxides and natural minerals.

Geochemical analyses (e.g., major and rare earth elements; REE) were performed at the Pheasant Memorial Laboratory (PML), Institute for Study of the Earth's Interior (ISEI), Okayama University at Misasa, Japan, following the procedures of Nakamura et al. (2003). Major elements, $\mathrm{Cr}$ and $\mathrm{Ni}$ concentrations were determined using
X-ray fluorescence (Phillips PW2400) with the full standard suite of the Geological Survey of Japan (GSJ). Each whole-rock sample weighing $500 \mathrm{mg}$ was mixed with $5 \mathrm{~g}$ of lithium tetraborate flux to produce homogeneous glass beads, and beads from all samples were prepared in duplicate. Major element compositions with errors $\leq 1 \%$, relative standard deviation (RSD) from the duplicate beads were included in this research. Loss on ignition (LOI) was determined gravimetrically also in duplicate and for some samples in triplicate if the RSD was larger than $0.03 \%$. Analytical conditions were similar to those described by Takei (2002) for this instrument.

Whole-rock REE concentrations were measured using inductively coupled plasma mass spectrometry (ICPMS) at the PML, based on the methods of Makishima and Nakamura (2006). During each ICP-MS analysis, basaltic standard (JB3) from the GSJ was used as a standard. To check the quality and accuracy JB3 samples were used as unknowns two to three times. Every sample was analyzed in duplicate and a few samples in triplicate, and agreement between analyses was excellent (errors were $\leq 2-3 \%$ RSD).

Whole-rock powdered samples weighing $\sim 20 \mathrm{mg}$ (each sample in duplicate) for ICP-MS analyses were decomposed in Teflon Bombs added with concentrated HF and $\mathrm{HClO}_{4}$ at $245{ }^{\circ} \mathrm{C}$ for 4 days to provide complete digestion. The solutions were then transferred to Teflon beakers, added with $0.1,0.6$ and $0.3 \mathrm{ml}$ of $\mathrm{HF}, \mathrm{HClO}_{4}$ and $\mathrm{HNO}_{3}$, respectively and agitated in an ultrasonic bath for 8 hours to achieve completely homogenous solutions. Fluoride residues produced by the initial acid attack were removed by repeated dissolution in $\mathrm{HClO}_{4}$ following the method of Yokoyama et al. (1999). Final solutions were prepared as $0.5 \mathrm{M} \mathrm{HNO}_{3}$ and were analyzed by ICP-MS.

\section{RESULTS}

\section{Petrography and mineral chemistry}

Eclogites in the Kaghan valley are classified into Group I and II eclogites on the basis of field occurrence, mineral paragenesis and chemical compositions. Mineralogical and compositional details of these two groups are described elsewhere (Rehman, 2007).

Group I eclogites are massive, and composed of garnet, clinopyroxene, quartz and amphibole with rare epidote/allanite and phengite. They contain rutile, ilmenite, apatite and abundant zircons as accessory minerals (Figs. $2 \mathrm{a}-2 \mathrm{c})$. The matrix consists of parallel oriented quartz-albite-amphibole symplectites with xenoblastic quartz and rutile. Quartz-albite-amphibole symplectites overgrow clinopyroxene and garnet indicating a later retrograde 

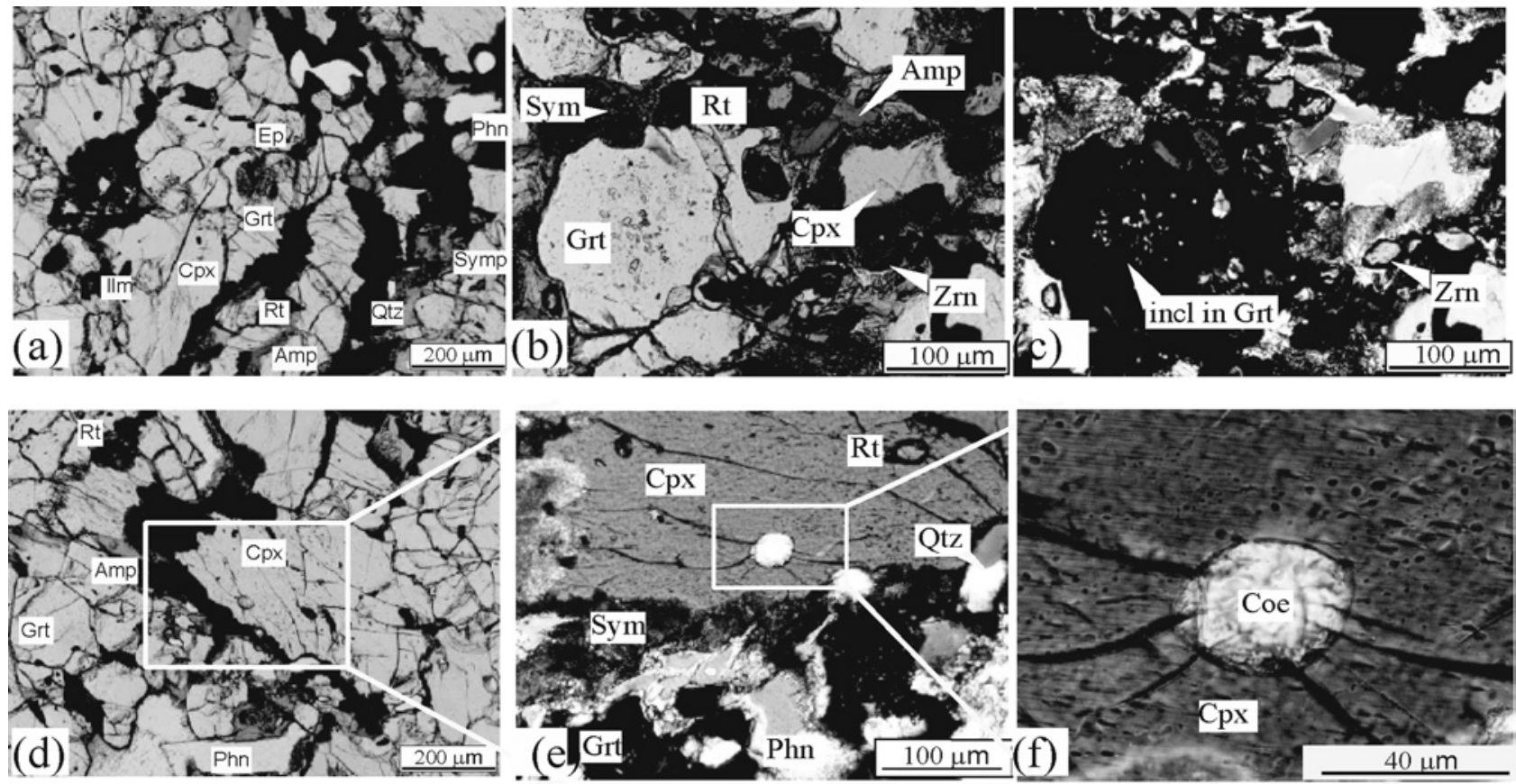

Figure 2. Textural features of Group I and II eclogites. (a) Photomicrograph of Group I eclogites. Garnet has fresh rims but spotted cores containing inclusions of quartz, albite, jadeite and phengite. Accessory rutile, ilmenite and zircons are abundant. (b) Group I eclogites with garnet porphyroblasts containing inclusions in the core portion. A euhederal zircon can be seen in the lower right of the field of view (plain polarized). (c) is the cross polarized view of " $b$ ". (d) Photomicrograph of Group II eclogites displaying garnet and coesite-bearing clinopyroxene, phengite with accessory rutile and ilmenite. Darker portions surrounding clinopyroxene are decompressed parts (symplectites). (e) Modified from Rehman et al. (2007), and is the enlarged portion of square marked in "d" in cross polarized light. (f) is further enlarged portion of the coesite inclusion in clinopyroxene (cross polarized).

(a)

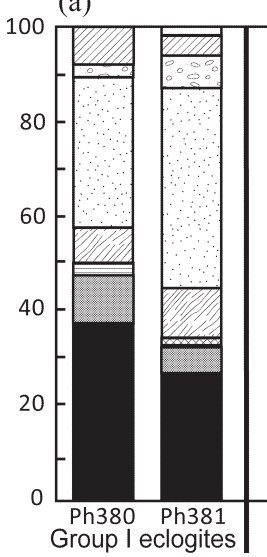

(b)

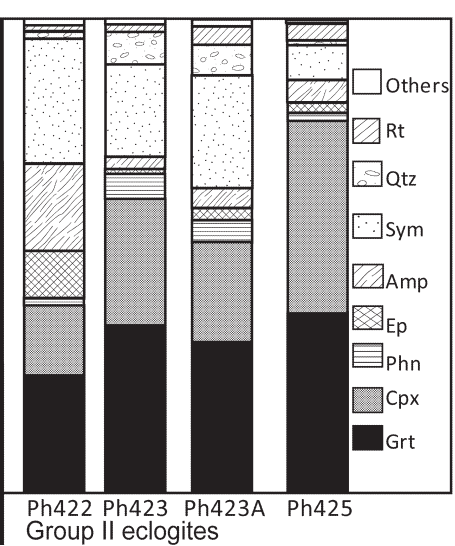

\begin{tabular}{|c|c|c|c|c|c|c|}
\hline \multirow[t]{2}{*}{ Minera } & \multirow[t]{2}{*}{\begin{tabular}{|l|} 
Group \\
Matrix \\
\end{tabular}} & \multicolumn{2}{|c|}{1 eclogites } & \multicolumn{3}{|c|}{ Group II eclogites } \\
\hline & & Grt & Cpx & & Grt & Cpx \\
\hline Grt & 0 & & 0 & & & 0 \\
\hline Cpx & 0 & 0 & & & 0 & \\
\hline Phn & 0 & 0 & & & 0 & 0 \\
\hline Ep & 0 & $\%$ & 0 & & 0 & 0 \\
\hline Amp & Ö & Ö & Oे & 0 & $\bigcirc$ & 0 \\
\hline Sym & & ○ & ? & 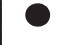 & $\bigcirc$ & : \\
\hline PI & 0 & 6 & 6 & & 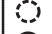 & 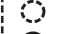 \\
\hline Qtz & 0 & 0 & 0 & & 0 & ? \\
\hline Rt & 0 & 0 & 0 & 0 & 0 & $\ddot{0}$ \\
\hline Aln & 0 & $\theta$ & 3 & 0 & $\%$ & \\
\hline Zrn & 0 & 0 & 0 & 0 & 0 & 3 \\
\hline
\end{tabular}

Figure 3. (a) Modal abundance (volume $\%$ ) of major mineral assemblage of Group I and II eclogites. Abbreviations for most of the minerals are adopted after Kretz (1983) except for Amp: amphibole and Sym: symplectites. The "Others" include kyanite, apatite, zircon and opaque. (b) Mineral occurrence of matrix constituents, and as inclusions in garnet and clinopyroxene from Group I and II eclogites. Filled circles represent abundant minerals in eclogite, open circles show rare occurrence and broken-lined circles indicate relics of a mineral or as inclusions. stage. Modal abundance, mineral assemblage and inclusion phases of Group I eclogites are shown in Figure 3.

Garnets in Group I eclogites have fresh rims and spotted cores containing inclusions of quartz, albite, jadeite and phengite (Figs. $2 \mathrm{~b}$ and $2 \mathrm{c}$ ). Few garnet grains also contain fine-grained inclusions of clinopyroxene. Chemical composition of garnets in Group I eclogites shows slight zonation (Table 1). Compositionally they are Almrich (68-79\%), Prp (15-23\%), Grs (9-15\%) except sample Ph381 in which the Grs contents are extremely low
$(<2 \%)$ and Sps contents are also very low $(<3 \%$; See $\mathrm{Ph} 378$ and $\mathrm{Ph} 380$ ). The Alm content increases from core to rim portion (in $\mathrm{Ph} 378$ but reverse in $\mathrm{Ph} 380$ ) whereas Prp shows irregular pattern (Table 1). Clinopyroxene grains are generally fresh at cores while transformed to symplectites at rims in most cases. They also contain inclusions of garnet, quartz, and minor epidote and zircon. Chemical composition of clinopyroxene in Group I eclogites is almost identical to clinopyroxene in Group II eclogites except having slightly higher contents in $\mathrm{FeO}$ 


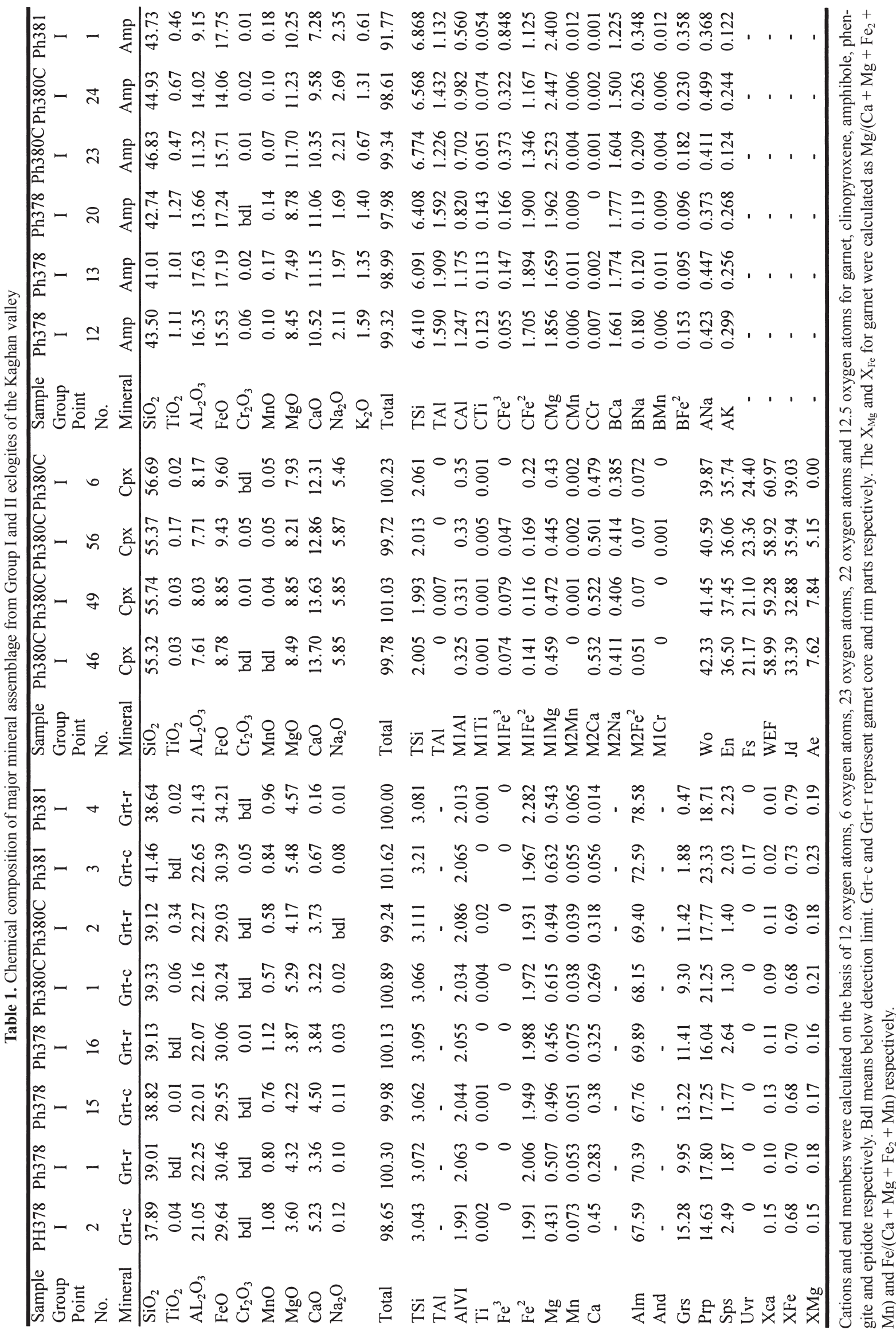




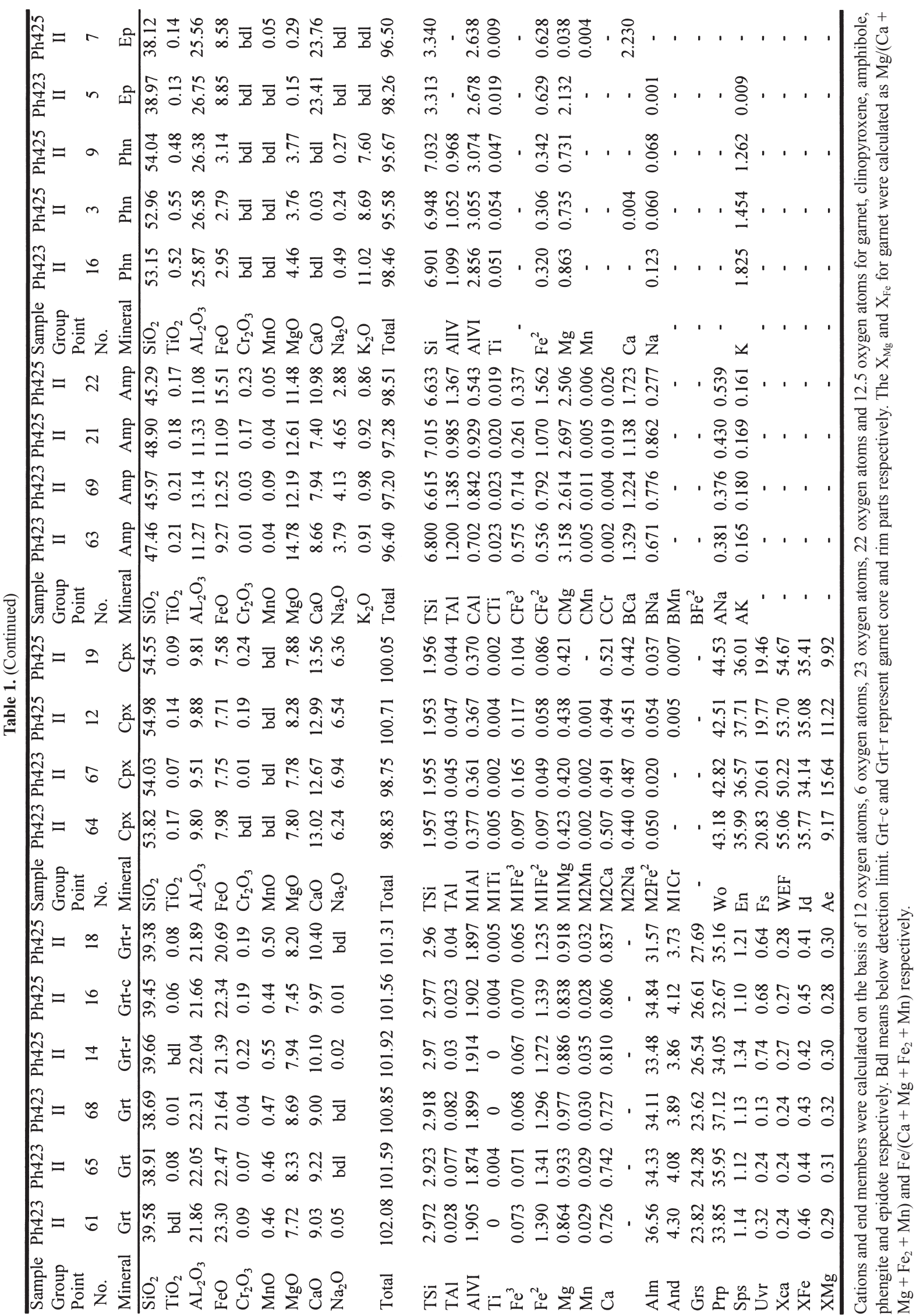




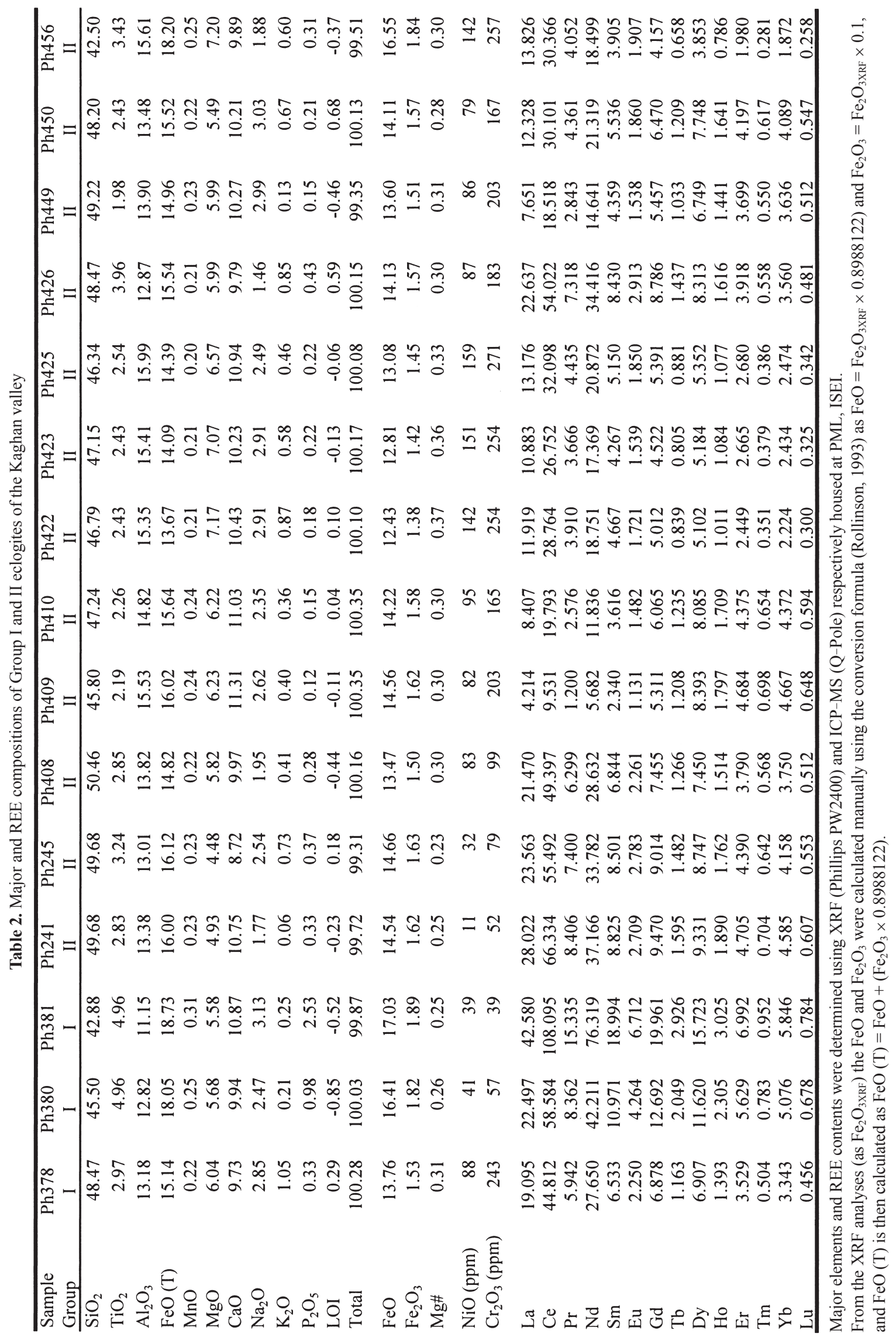



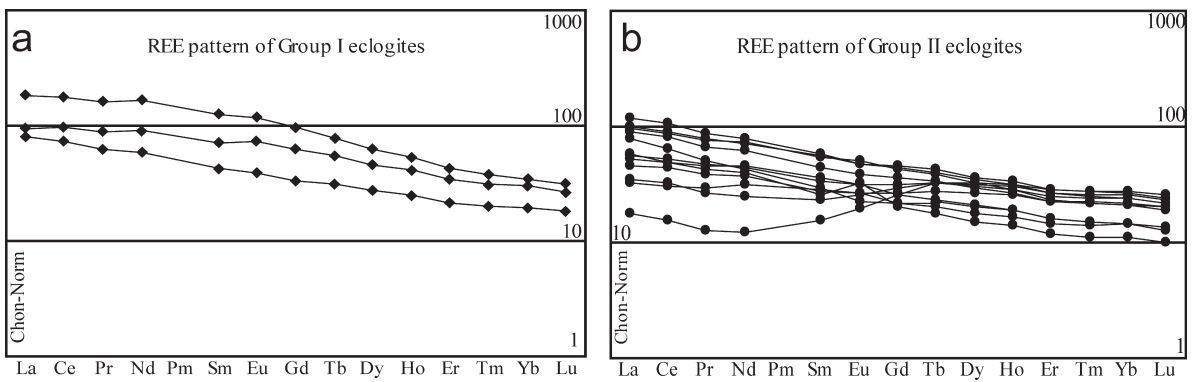

Figure 4. Chondrite-normalized REE diagrams of Group I (a) and II (b) eclogites. The chondrites values were taken from $\mathrm{C} 1$ chondrite after Sun and McDonough (1989).

and $\mathrm{MgO}$. The end-members of clinopyroxene show slight variation in chemical composition from those of Group II eclogites (Table 1).

Group II eclogites occur as isolated boudines or lenses and are relatively fresh. Texturally most of Group II eclogites are slightly coarse-grained ( $>250 \mu \mathrm{m}$ in size). They have a mineral assemblage of garnet + clinopyroxene + quartz/coesite + phengite + rutile + amphibole + epidote + kyanite with minor zircon. The presence of coesite inclusion in clinopyroxene indicates UHP grade metamorphic equilibrium conditions (Figs. 2d-2f). Some of the eclogite samples are fine to medium-grained $(<150$ $\mu \mathrm{m}$ in size) and contain mostly retrograded clinopyroxene, garnet (with amphibolitized rims) and amphibole. Abundant quartz-albite-amphibole symplectites are common (Figs. 2a and 2d).

Garnets in Group II eclogites contain inclusions of quartz, phengite, epidote, rutile and ilmenite. Some garnet grains display aligned textures and contain fine-grained inclusions of clinopyroxene, quartz, epidote, and rutile at mantle portions indicating its growth during eclogite facies metamorphism while rim portions are fresh and inclusion-free, thus, indicating peak-P. They have dark and inclusion-rich cores and inclusion-free rims. They are relatively uniform in composition. However, slight chemical zonation from core to rim is observed in some grains (Rehman et al., 2007). Compared to garnets of Group I eclogites, garnets of Group II eclogites are poor in Alm (32-37\%) and rich in Prp (33-37\%) contents. They are rich in Grs (24-28\%) contents. The contents of Sps are almost same $(<2 \%)$ in garnets of both groups. The Alm content decreases from core to rim portion whereas Prp shows reverse pattern (Table 1, sample Ph425). Thus, the garnet zonation and compositional variation suggest prograde metamorphic growth. The $\mathrm{X}_{\mathrm{Mg}}$ content in sample Ph423 ranges from 0.29 to 0.32 ; similarly, in sample Ph425 it ranges from 0.28 to 0.30 . Similarly the $X_{\mathrm{Mg}}$ content at rim is higher compared to core portions in both samples described above. Clinopyroxene contains coesite inclusions in its rim part (Fig. 2e). Amphibole grows over clinopyroxene and garnet at their rims, showing retrograde stage (Fig. 2d). Clinopyroxenes in Group II eclog- ites are mostly uniform in composition despite of whether determined from granoblasts or as an inclusion within garnet (Table 1). However, the $\mathrm{Na}_{2} \mathrm{O}$ contents of clinopyroxene in Group II eclogites are slightly higher ( 1\%) compared with Group I eclogites. Jadeite contents are rather uniform in most of the clinopyroxene grains with a range of 33 to $39 \%$. However the aegirine content varies from grain to grain (5-16\%). Amphiboles also show similar compositional pattern, i.e. mostly uniform however in certain oxide elements e.g., $\mathrm{TiO}_{2}, \mathrm{FeO}$ and $\mathrm{Al}_{2} \mathrm{O}_{3}$ the contents $(\mathrm{wt} \%)$ are higher in Group I compared with Group II eclogites. Generally, they are composed of hornblende, tschermakite, edenite and barroisite (according to the classification of Leake et al., 1997). Some of the amphiboles occur as secondary products along the rims of garnet and clinopyroxene, and as large granoblasts along the major foliation. Chemical compositions of amphiboles are close to the end-member compositions with $\mathrm{Si}>6.9, \mathrm{Fe}^{3+} /\left(\mathrm{Fe}^{3+}\right.$ $+\mathrm{Al})$ in the M2 site is $<0.9$, and $(\mathrm{Na}) \mathrm{M} 4$ ranges from 0.37 to 0.54 (see Table 1). Epidote is rare in Group I eclogites, and abundant in Group II eclogites. Compositional variation in epidote of Group II eclogites is shown in Table 1. There is no evident compositional difference between epidote in the matrix and that enclosed in garnet and clinopyroxene, but some crystals in the matrix are apparently zoned. Phengite is abundant in Group II eclogites, while less common in Group I eclogites. Its chemical composition is shown in Table 1.

Peak $P-T$ conditions were defined by the mineral assemblage garnet (fresh rim) + clinopyroxene (fresh rim) + epidote + coesite \pm rutile + liquid. To obtain true or nearly true peak $P-T$ conditions, garnet and clinopyroxene grains were selected which share fresh rims and have no symplectites along their sharing borders. Similarly $P-T$ conditions for the retrograde stage were deduced from quartzalbite-amphibole symplectitic part.

\section{Whole-rock major elements and REE geochemistry}

Major element compositions of most eclogitic samples have basaltic compositions with $\mathrm{SiO}_{2}$ contents of 42 to 50 $w t \%$ (Table 2) and they display weak tholeiitic differenti- 
ation trends, as reported by earlier workers (Honegger et al., 1982; Papritz and Rey, 1989; Spencer et al., 1995). However, Group I eclogites are rich in $\mathrm{FeO}$ and $\mathrm{TiO}_{2}$, suggesting a different origin from basalts. Group II eclogites are rich in $\mathrm{SiO}_{2}$ and $\mathrm{Al}_{2} \mathrm{O}_{3}$ and poor in total $\mathrm{FeO}$ and $\mathrm{TiO}_{2}$. The $\mathrm{TiO}_{2}$ content ranges between 1.28 to $4.96 \mathrm{wt} \%$ with the highest values for zircon-rich Group I eclogites. The $\mathrm{Mg} \#$ calculated as $\mathrm{MgO} /(\mathrm{MgO}+\mathrm{FeO})$ of Group I eclogites is lower $(<0.26$, except $\mathrm{Ph} 378)$ whereas the $\mathrm{Mg} \#$ is higher $(>0.30)$ in most samples of Group II eclogites (Table 2).

The chondrite-normalized REE abundances in Figure 4 show that Group I eclogites are two to three times rich in REE compared to Group II eclogites. However, both groups of eclogites display flat patterns with slight fractionation of HREE from LREE (Fig. 4). The LREE enriched patterns show a progressive decrease from La to $\mathrm{Lu}$, resulting in chondrite-normalized abundance ratios $(\mathrm{La} / \mathrm{Lu})_{\mathrm{N}}$ of $0.7-5.9$ and $(\mathrm{La} / \mathrm{Sm})_{\mathrm{N}}$ ratio of 1.8-4.4. In addition to the higher abundance ratios, LREE concentrations are higher in Group I eclogites compared to Group II eclogites (Table 2, Fig. 4). The REE patterns are probably controlled by the modes of garnet and zircon in Group I eclogites, and garnet and epidote in Group II eclogites, which have extremely different REE characteristics. Similarly, the LREE/MREE fractionation $(\mathrm{La} / \mathrm{Sm})_{\mathrm{N}}=2.6$ of Group II eclogites slightly differs from those of Group I eclogites, which have $(\mathrm{La} / \mathrm{Sm})_{\mathrm{N}}$ ratios of 2.3. The pattern of enrichment of REE in this study, and of other trace elements reported elsewhere (Papritz and Rey, 1989; Spencer et al., 1995; Rehman, 2007) is similar to the enrichment pattern for tholeiitic and within-plate-basalts of Pearce (1982).

The presence of large-size zircons $(>250 \mu \mathrm{m})$ in Group I eclogites and their zoning pattern indicate their formation in gabbroic protolith (Rehman, 2007). In contrast, Group II eclogites contain a few small-sized $(<100$ $\mu \mathrm{m})$ unzoned zircons, indicating different protolith. In addition to major and trace elements geochemistry, the abundance of zircon in both groups of eclogites, and the zircon morphology favor our interpretation of assigning different types of protolith for the Kaghan valley eclogites.

\section{Pressure-temperature-time path}

The Kaghan valley eclogites were derived from the Panjal Trap continental basalts of Permian to Early Triassic age (Honegger et al., 1982). The initiation of the basaltic activity at 267 to $253 \mathrm{Ma}$ is well constrained by the isotope ages (Honegger et al., 1982; Spencer et al., 1995; Kaneko et al., 2003; Rehman et al., 2006). The U-Pb concordant

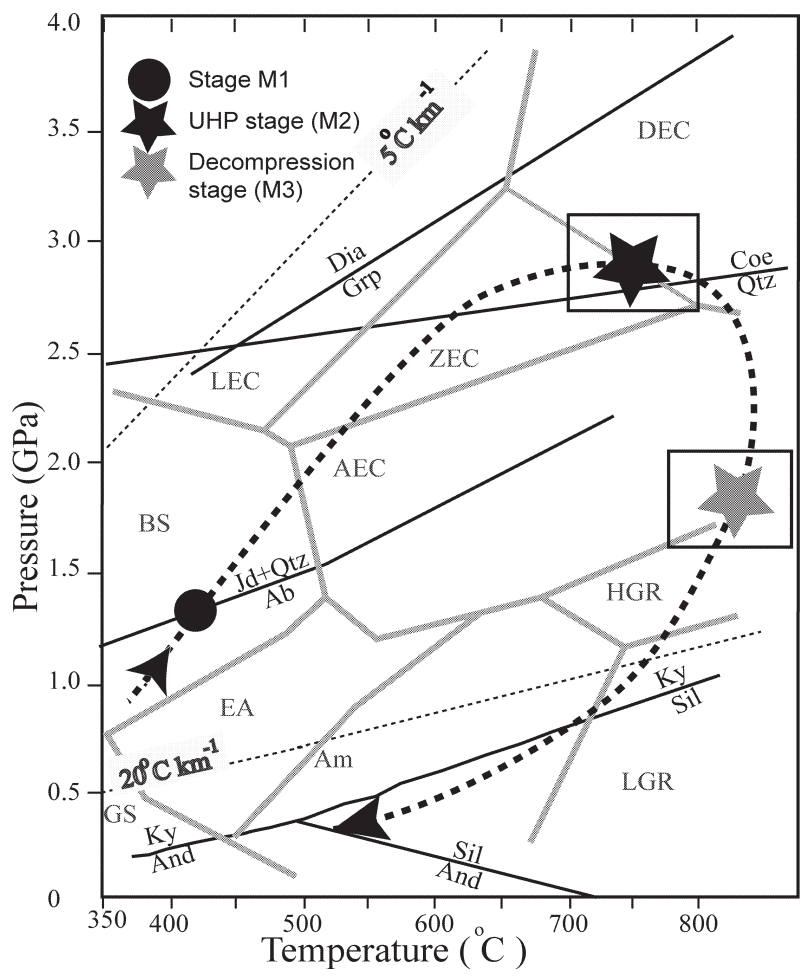

Figure 5. Three phases of metamorphic evolution for the Kaghan valley eclogites with average $P-T$ estimates. Phase 1 is deduced from garnet core having inclusions of quartz, albite and jadeite. Phase 2 represents an UHP stage (coesite-stable field) deduced from the garnet-rim portions and clinopyroxene. Decompression stage is represented by phase 3 . The path of metamorphism follows a clockwise pattern. Metamorphic facies boundaries and reaction curves are modified from Holdaway (1971), Bundy (1980), Holland (1980), Bohlen and Boettcher (1982), Maruyama et al. (1996) and, Oh and Liou (1998). Abbreviations: AM, amphibolite facies; BS, blueschist facies; EA, epidote-amphibolite facies; GS, greenschist facies; HGR, high-pressure granulite subfacies; LGR, low-pressure granulite subfacies; AEC, amphibole-eclogite subfacies; DEC, dry-eclogite subfacies; LEC, lawsoniteeclogite subfacies; ZEC, zoisite-eclogite subfacies.

ages of $180 \pm 5 \mathrm{Ma}$ (mantle portion) and $114 \pm 6 \mathrm{Ma}$ (rim portion) obtained from zircons of the Kaghan valley eclogites (Group I) may suggest an overgrowth of the zircon grains due to periodic addition of the magmatic material to the protolith (Rehman et al., 2006).

Closure of the Tethys sea and transformation of the Kaghan valley basalts and gabbroic rocks into eclogites started with the initiation of the India-Asia collision at about $55 \mathrm{Ma}$ (Patriat and Achache, 1984; Klootwijk et al., 1992; Beck et al., 1995). Eclogite facies metamorphism in the leading-edge of the Indian plate was initiated at $49 \pm$ $6 \mathrm{Ma}$ when these rocks reached to a depth of about 60 to $70 \mathrm{~km}$ (Tonarini et al., 1993; Spencer et al., 1995). The process of eclogite facies metamorphism was continued and upon reaching to about $100 \mathrm{~km}$ depth the UHP metamorphic event took place at $46 \pm 4 \mathrm{Ma}$ (Kaneko et al., 
2003). At this depth coesite was trapped as inclusion in omphacite of eclogite and in zircon of felsic gneiss. In coesite-stable field a probable slab break-off occurred in the leading-edge of the Indian plate northern margin.

To reconstruct the $P-T-t$ path and to estimate the peak $P-T$ conditions of eclogites from the Kaghan valley we applied multiequilibrium calculations using THERMOCALC software. Apparently three stages of metamorphism can be deduced from the petrographic features and mineral inclusions (Fig. 5). The first stage (M1) is deduced from the inclusion paragenesis ( $\mathrm{Jd}+\mathrm{Qtz}+\mathrm{Ab}$ inclusions in garnet cores) and indicates prograde garnet growth. The second stage (M2) is estimated from the rim compositions of adjacent garnet and clinopyroxene, phengite, epidote, amphibole and coesite (Fig. 5). The average $P-T$ conditions of this stage were $2.8 \mathrm{GPa}$ and $762 \pm 46$ ${ }^{\circ} \mathrm{C}$ (significant fitness was 1.29 , for $95 \%$ confidence level the value is $<1.49$ ) by the following set of reactions. The abbreviations used for minerals and their end members are adopted from THERMOCALC with its internally consistent data set (Holland and Powell, 1998).

1) coe $=q t z$

2) $4 \mathrm{mu}+4 \mathrm{di}+\mathrm{gl}+\mathrm{q}=4 \mathrm{cel}+2 \mathrm{jd}+2 \mathrm{cz}+\mathrm{py}$

3) $16 \mathrm{acm}+19 \mathrm{ts}=16 \mathrm{jd}+3 \mathrm{tr}+16 \mathrm{ep}+14 \mathrm{py}$ $+8 \mathrm{H}_{2} \mathrm{O}$

4) $19 \mathrm{mu}+21 \mathrm{hed}+16 \mathrm{~cm}+8 \mathrm{tr}=19 \mathrm{cel}+21 \mathrm{di}$ $+16 \mathrm{jd}+8 \mathrm{fep}+7 \mathrm{alm}+4 \mathrm{H}_{2} \mathrm{O}$

The average $P-T$ conditions from the decompression stage (M3) were deduced from the quartz-albite-amphibole symplectitic part. Since, it is difficult to obtain the average $P-T$ conditions with a few mineral compositions when applying through THERMOCALC, we included the mineral compositions of garnet (amphibolitized portion near rim part) + clinopyroxene (amphibolitized portion near rim) + amphibole (portions that surround clinopyroxene and are secondary after clinopyroxene) + albite (from symplectite part) + quartz + liquid. The end-members having greater uncertainty (e.g., Grt and Cpx which are not in equilibrium with symplectitic part) were removed from the calculation in order to obtain the $P-T$ estimates of the decompression stage. The average $P-T$ estimates obtained, thus, show $1.8 \mathrm{GPa}$ and $859 \pm 59^{\circ} \mathrm{C}$ (significant fitness was 1.61 , for $95 \%$ confidence level the value is $<1.39$ ) (Fig. 5) from the mineral assemblage of Grt + $\mathrm{Cpx}+\mathrm{Phn}+\mathrm{Ep}+\mathrm{Qtz}+\mathrm{Amp}+\mathrm{An}$ (symplectite part of plagioclase anorthite content calculated) + liq, by the following reactions.

1) $3 \mathrm{tr}+2 \mathrm{py}+4 \mathrm{gr}=12 \mathrm{di}+3 \mathrm{ts}$

2) $9 \mathrm{hed}+4 \mathrm{tr}+3 \mathrm{an}=20 \mathrm{di}+3 \mathrm{alm}+7 \mathrm{q}+4 \mathrm{H}_{2} \mathrm{O}$
3) $11 \mathrm{tr}+24 \mathrm{cz}+10 \mathrm{py}+4 \mathrm{east}=4 \mathrm{mu}+24 \mathrm{di}+23 \mathrm{ts}$

4) $15 \mathrm{hed}+6 \mathrm{cz}+\mathrm{ann}=\mathrm{mu}+3 \mathrm{fact}+7 \mathrm{gr}+\mathrm{alm}$

\section{DISCUSSION AND CONCLUSION}

Based on field observations, detailed petrography, major elements and REE geochemistry, and mineral chemistry, metamorphic evolution and a schematic tectonic model for the Kaghan valley eclogites are presented (Fig. 6).

Two types of source rocks were assigned to the Kaghan valley eclogites. Group I eclogites with higher $\mathrm{FeO}-\mathrm{TiO}_{2}$, higher trace element contents and with abundant zircons (zoned and rich in U-Th contents) are considered as derived from gabbroic protolith. Our interpretation of assigning a gabbroic protolith is supported by multi-isotope ratios reported elsewhere (Rehman, 2007). Whereas Group II eclogites with lower $\mathrm{FeO}-\mathrm{TiO}_{2}$ and lower trace element contents are the products of basalts and this interpretation is well constrained with the results reported by previous workers (Honegger et al., 1982; Papritz and Rey, 1989; Spencer et al., 1995).

Magmatic activity in the Himalayan region started with basaltic extrusions at the northern margin of the Indian plate in the Permian (about $267 \mathrm{Ma} \sim$ ) when the Indian continent was drifting northward (Honegger et al., 1982; Rehman, 2007). These basalts and associated gabbroic sills/dikes were emplaced when the Indian plate was passing over an unknown hot spot (Fig. 6a). The mantle material gushed out through a plume and associated feeder dikes in a shallow marine environment probably more than once. The U-Pb concordant age of $180 \mathrm{Ma}$ from mantle portions of zircon of Group I eclogites (Rehman, 2007) reveals overgrowth of zircon in the later stage (Fig. 6b). Collision of the Kohistan-Ladakh Island Arc (KLIA) with the Asian continental plate is marked by the $114 \mathrm{Ma}$ (zircon rim portions) and is well constrained with the earlier reported ages for the Asian plate contact with the KLIA (Khan et al., 1997).

Group I eclogites of gabbroic origin are zircon-rich and are composed of Alm-rich and Prp-poor garnet, thus showing mineral chemistry with high contents in Fe. Similarly, amphiboles from this group also have higher concentrations in Fe-Ti (Table 1). On the other hand, Group II eclogites of basaltic origin are zircon-poor and are composed of Alm-poor and Prp-rich garnet. Although, from the magmatic emplacement till the eclogite facies metamorphism of these mantle-derived rocks, their mineral assemblage may change considerably but as an isodynamic system the over-all chemistry may remain unchanged and the effect of fluids/liquids in mafic rocks might be negligible (Spandler et al., 2004). This difference in mineralogy and chemical composition, thus, sup- 
(a)

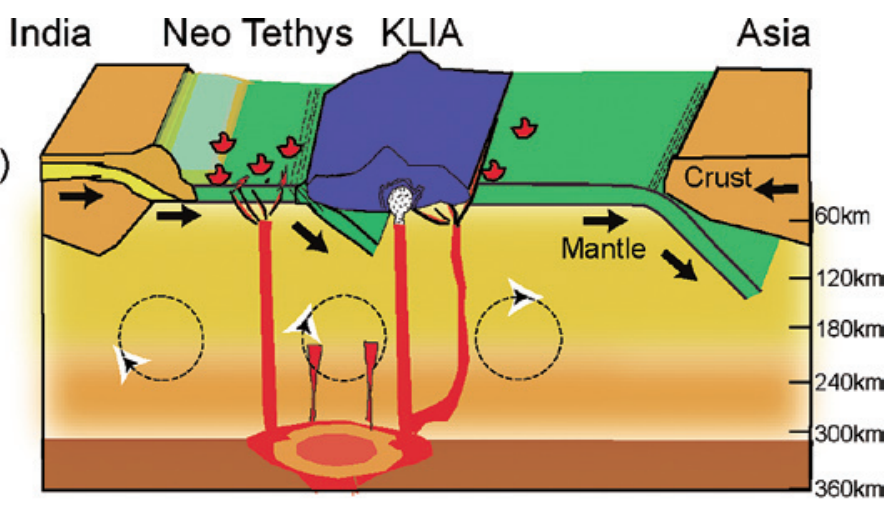

(b)

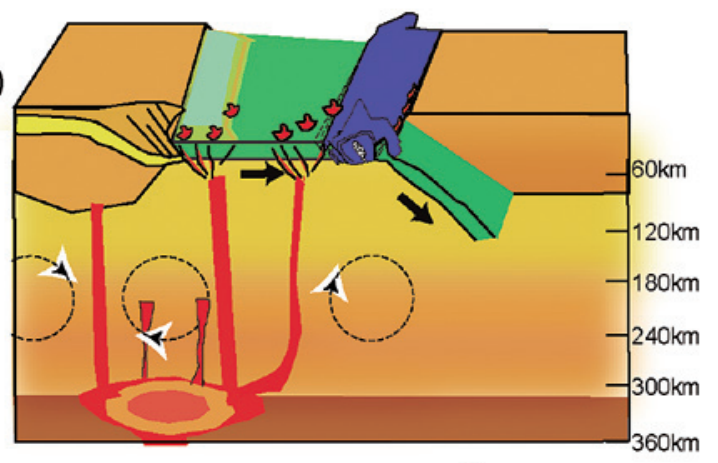

(c)

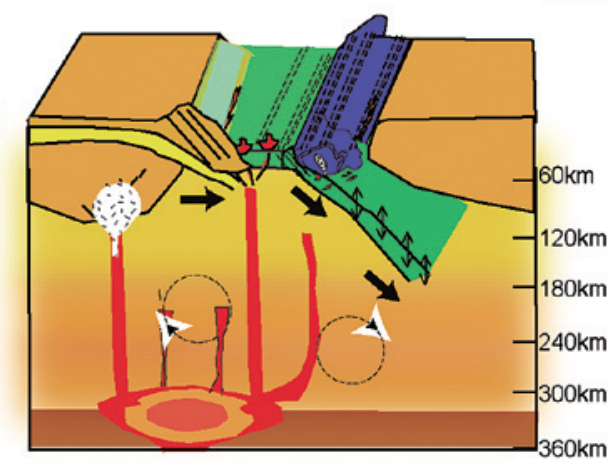

(d)

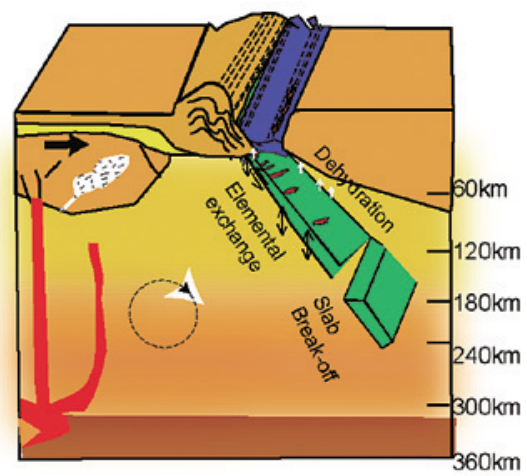

(e)

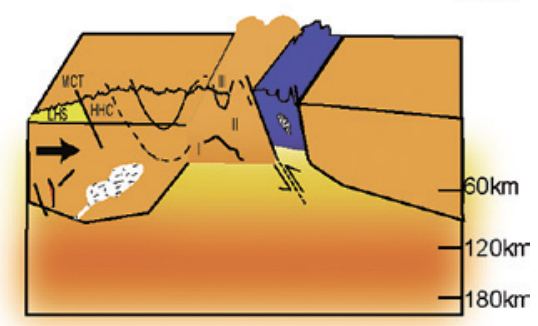

Figure 6. Schematic tectonic model of the main crustal blocks and intervening oceanic parts representing the Himalayan volcanic cycle, preceding collision/subduction process and related metamorphism. The diagram illustrates stages from (a)-(e). (a) Initiation of magmatic activity in the Indian plate northern margin $(\mathrm{U}-\mathrm{Pb}$ zircon age of $267 \mathrm{Ma}$, from core portions). (b) Timing of collision of the KLIA with the Asian plate (U-Pb zircon age of 114-103 Ma, from rim portions). The U-Pb zircon age of $180 \mathrm{Ma}$ (from zircon mantle portions) indicates zircon overgrowth probably during the second magmatic activity. (c) Northward movement of the Indian plate and its subduction beneath the Asian plate. Beginning of eclogite facies metamorphism at $49 \mathrm{Ma}$ when the Indian plate leading-edge was subducted to $>60 \mathrm{~km}$. (d) The UHP metamorphic event at $46 \mathrm{Ma}$, when the Indian slab reached to a depth of about $100 \mathrm{~km}$. During this time a probable slab break-off occurred and the exhumation of these eclogites started. (e) This stage illustrates a largescale deformation and later stage Barrovian type metamorphism of the Himalayan chain in the Neogene. The three tectonic units (I, II and III) of the HHC were deformed and folded. Red marks in the Tethys show mantle derived protolith of eclogites. 
port our idea of assigning different source to both groups of eclogites.

Both groups of eclogites underwent eclogite facies metamorphism when the Indian plate leading-edge was subducted beneath the Asian plate (Fig. 6c). The $P-T-\mathrm{t}$ path of these eclogites shows at least three distinct metamorphic stages. Stage M1 (deduced from the inclusion paragenesis in garnet core) indicates a prograde garnet growth. Stage M2 records the UHP metamorphic phase in these eclogites when the Indian plate rocks reached to about $100 \mathrm{~km}$ depth (Fig. 6d). Stage M3 represents the decompression phase, deduced from the symplectitic part.

The subduction of the Indian plate and its collision with the Asian continent resulted in a regional scale metamorphism in the Himalayan chain (Rehman et al., 2007 and references there in). Slab pull of the oceanic part of the Indian plate, due to its high density, produced thrusting and imbrications of the rare part of the subducting crust. After the collision, a large-scale deformation related Barrovian-type metamorphism of the Himalayan stage (Rehman et al., 2007) in the Neogene took place in the Himalayan region of the northern Indian continent (Fig. $6 \mathrm{e})$.

\section{ACKNOWLEDGMENTS}

The first author is grateful for the cooperation of PML staff, especially Prof. A. Makishima, Dr. T. Moriguti, Dr. R. Tanaka, Dr. T. Ota, Ms. C. Sakaguchi and other researchers for their help in analytical procedures and scientific discussion. Mr. Y. Oozono and Mr. M. Hoashi of the Kagoshima University (KU) are thanked for their support in the electron microprobe analyses. Thanks to Dr. Stephen Cother of the KU for English check. Thanks to Dr. A. B. Kausar of the Geological Survey of Pakistan for providing logistical support in the field work. Comments from two anonymous reviewers are highly appreciated which substantially improved earlier versions of the manuscript. Dr. M. Owada is acknowledged for efficient correspondence and editorial advice. Geochemical work was carried out under the Visiting Researcher's Program of the Institute for the Study of the Earth's Interior, Okayama University, Misasa, Japan and was supported by the Ministry of Education, Culture, Sports, Science and Technology, Japan to E.N. and by the program of the Center of Excellence for the 21st Century in Japan.

\section{REFERENCES}

Beck, R.A., Burbank, D.W., Sercombe, W.J., Riley, G.W., Barndt, J.K., Berry, J.R., Afzal, J., Khan, A.M., Jurgen, H., Metje, H., Cheema, A., Shafique, N.A., Lawrence, R.D. and Khan, M.A.
(1995) Stratigraphic evidence for an early collision between northwest India and Asia. Nature, 373, 55-58.

Bohlen, S.R. and Boettcher, A.L. (1982) The quartz-coesite transformation: A pressure determination and effects of other components. Journal of Geophysical Research, 87, 70737078 .

Bundy, F.P. (1980) The P, T phase and reaction diagram for elemental carbon. Journal of Geophysical Research, 85, 69306936.

Greco, A., Martinotti, G., Papritz, K., Ramsay, J.G. and Rey, R. (1989) The Himalayan crystalline rocks of the Kaghan Valley (NE-Pakistan). Eclogae Geologicae Helvetiae, 82, 629-653.

Guillot, S., Garzanti, E., Baratoux, D., Marquer, D., Mahéo, G. and de Sigoyer, J. (2003) Reconstructing the total shortening history of the NW Himalaya. Geochemistry Geophysics Geosysetems, 4(1): 1064, doi:10.1029/2002GC000484.

Holdaway, M.J. (1971) Stability of andalusite and the aluminum silicate phase diagram. American Journal of Science, 271, 97-131.

Holland, T.J.B. (1980) The reaction albite $=$ jadeite + quartz determined experimentally in the range $600-1200{ }^{\circ} \mathrm{C}$. American Mineralogist, 65, 129-134.

Holland, T.J.B. and Powell, R. (1998) An internally consistent thermodynamic data set for phases of petrological interest. Journal of Metamorphic Geology, 16, 309-343.

Honegger, K., Dietrich, V., Frank, W., Gansser, A., Thöni, M. and Trommsdorf, V. (1982) Magmatism and metamorphism in the Ladakh Himalaya (the Indus-Tsangpo suture zone). Earth and Planetary Science Letters, 60, 253-292.

Kaneko, Y., Katayama, I., Yamamoto, H., Misawa, K., Ishikawa, M., Rehman, H.U., Kausar A.B. and Shiraishi, K. (2003) Timing of Himalayan ultrahigh-pressure metamorphism: sinking rate and subduction angle of the Indian continental crust beneath Asia. Journal of Metamorphic Geology, 21, 589-599.

Khan, M.A., Stern, R.J., Gribble, R.F. and Windley, B.F. (1997) Geochemical and isotopic constraints of subduction polarity, magma source and paleography of Kohistan intra-oceanic arc, northern Pakistan Himalaya. Journal of Geological Society of London, 154, 935-946.

Klootwijk, C.T., Gee, J.S., Pierce, J.W., Smith, G.M. and McFadden, P.L. (1992) An early India-Asia contact: palaeomagnetic constraints from Ninetyeast Ridge, ODP Leg 121. Geology, 20, 395-398.

Kretz, R. (1983) Symbols for rock-forming minerals. American Mineralogist, 68, 277-279.

Leake, B.E., Woolley, A.R., Arps, C.E.S., Birch, W.D., Gilbert, M.C., Grice, J.D., Hawthorne, F.C., Kato, A., Kisch, H.J., Krivovichev, V.G., Linthout, K., Laird, J., Mandarino, J.A., Maresch, W.V., Nickel, E.H., Rock, N.M.S., Schumacher, J.C., Smith, D.C., Stephenson, N.C.N., Ungaretti, L., Whittaker, E.J.W. and Guo, Y.Z. (1997) Nomenclature of amphiboles: report of the subcommittee on amphibole of the International Mineralogical Association, Commission on New Minerals and Mineral Names. Canadian Mineralogist, 35, 219-246.

Lombardo, B. and Rolfo, F. (2000) Two contrasting eclogite types in the Himalaya: implications for the Himalayan orogeny. Journal of Geodynamics, 30, 37-60.

Makishima, A. and Nakamura, E. (2006) Determination of Major, Minor and Trace Elements In Silicate Samples by ICP-SFMS Applying Isotope Dilution-Internal Standardisation (ID-IS) 
and Multi-Stage internal Standardisation. Geostandard Newsletter, 30, 245-271.

Maruyama, S., Liou, J.G. and Terabayashi, M. (1996) Blueshists and eclogites of the world and their exhumation. International Geology Review, 38, 485-594.

Nakamura, E., Makishima, A., Moriguti, T., Kobayashi, K., Sakaguchi, C., Yokoyama, T., Tanaka, R., Kuritani, T. and Takei, H. (2003) Comprehensive geochemical analyses of small amounts $(<100 \mathrm{mg})$ of extraterrestrial samples for the analytical competition related to the sample-return mission, MUSES-C. The Institute of Space and Austronomical Science Report, 16, 49-101.

O’Brien, P.J., Zotov, N., Law, R., Khan, M.A. and Jan, M.Q. (2001) Coesite in Himalayan eclogite and implications for models of India-Asia collision. Geology, 29, 435-438.

Oh, C.W. and Liou, J.G. (1998) A petrogenetic grid for eclogite and related facies under high-pressure metamorphism. Island Arc, 7, 36-51.

Papritz, K. and Rey, R. (1989) Evidence for the occurrence of Permian Panjal Trap Basalts in the Lesser and Higher Himalayas of the western syntaxis area, NE Pakistan. Ecologae Geologicae Helvetiae, 82, 603-627.

Parish, R.R., Gough, S.J., Searle, M.P. and Waters, D.L. (2006) Plate velocity exhumation of ultrahigh-pressure eclogites in the Pakistan Himalaya. Geology, 34, 989-992.

Patriat, P. and Achache, J. (1984) India-Asia collision chronology has implications for crustal shortening and driving mechanism of plates. Nature, 311, 615-621.

Pearce, J.A. (1982) Trace element characteristics of lavas from destructive plate boundaries. In Andesites (Thorpe, R.S. Ed.). John Wiley and Sons, New York, 525-548.

Rehman, H.U. (2007) The Ultrahigh-pressure eclogites in Kaghan valley, Pakistan Himalaya: Origin and metamorphic evolution. pp. 366, PhD thesis, Kagoshima University, Kagoshima, Japan.

Rehman, H.U., Yamamoto, H., Kobayashi, K., Makishima, A. and Nakamura, E. (2006) Multistage Mixing of the Himalayan UHP Eclogites: Geochemical and Geochronological Evidence. Abstracts with Programs of Geological Society of
America Annual Meeting, 38, Geological Society of America, Philadelphia, PA, 108442.

Rehman, H.U., Yamamoto, H., Kaneko, Y., Kausar, A.B., Murata, M. and Ozawa, H. (2007) Thermobaric Structure of the Himalayan Metamorphic Belt in Kaghan Valley, Pakistan. Journal of Asian Earth Sciences, 29, 390-406.

Rollinson, H. (1993) Using geochemical data: evaluation, presentation, interpretation. pp. 344, Longman, London.

Spandler, C., Hermann, J., Arculus, R.J. and Mavrogenes, J.A., (2004) Geochemical heterogeneity and element mobility in deeply subducted oceanic crust; insights from high-pressure mafic rocks from New Caledonia. Chemical Geology, 206, 21-42.

Spencer, D.A., Tonarini, S. and Pognante, U. (1995) Geochemical and $\mathrm{Sr}-\mathrm{Nd}$ isotopic characterisation of Higher Himalayan eclogites (and associated metabasites). European Journal of Mineralogy, 7, 89-102.

Sun, S.S. and McDonough, W.F. (1989) Chemical and isotopic systematics of oceanic basalts: implications for mantle composition and processes. In Magmatism in the Ocean Basins (Saunders, A.D. and Norry, M.J. Eds.). Geological Society of London Special Publication, 42, 313-345.

Takei, H. (2002) Development of precise analytical techniques for major and trace element concentrations in rock samples and their applications to the Hishikari Gold Mine, southern Kyushu, Japan. Ph.D Thesis, Okayama University, Misasa, Japan.

Tonarini, S., Villa, I.M., Oberli, F., Meier, M., Spencer, D.A., Pognante, U. and Ramsay, J.G. (1993) Eocene age of eclogite metamorphism in Pakistan Himalaya: Implications for IndiaEurasia collision. Terra Nova, 5, 13-20.

Yokoyama, T., Makishima, A. and Nakamura, E. (1999) Evaluation of the coprecipitation of incompatible traceelements with fluoride during silicate rock dissolution by acid digestion. Chemical Geology, 157, 175-187.

Manuscript received February 22. 2008

Manuscript accepted July 9, 2008

Manuscript handled by Yasuhito Osanai 